\title{
Perwujudan Kohesi dan Koherensi Tulisan Makalah Mahasiswa
}

\author{
Sakrim', Mariam Ulfa ${ }^{2}$ \\ STKIP PGRI Bangkalan \\ sakrim@stkippgri-bkl.ac.id ${ }^{1}$, mariamulfa@,stkippgri-bkl.ac.id ${ }^{2}$
}

DOI: $\underline{\text { https://doi.org/10.32528/bb.v6i1.4379 }}$

First received: 01-03-2021 Final proof received: 10-03-2021

\begin{abstract}
ABSTRAK
Tulisan ini bertujuan untuk membahas dan mengkaji tulisan mahasiswa dari segi kepaduan antar kalimat dan kepaduan antar paragraf. Objek penelitian ini adalah makalah mahasiswa. Makalah menjadi indikator ciri dan pola mahasiswa dalam menulis. Berdasarkan tulisan dapat diketahui alur dan pola berpikir. Oleh sebab itu kepaduan antar kalimat dan antar paragraf sangat penting agar tulisan dapat dipahami dengan baik dan memiliki struktur yang sistematis. Kohesi dan koherensi serta tatanan bahasa yang benar menjadi sangat penting untuk membuat alur berpikir yang dapat diterima dan dipahami oleh pembaca. Data dalam penelitian ini adalah tulisan hasil makalah mahasiswa prodi pendidikan bahasa dan sastra Indonesia. Pengumpulan data dalam penelitian ini menggunakan metode dokumentasi. Teknik pengumpulan data menggunakan Teknik baca catat. Berdasarkan hasil penelitian ditemukan bahwa mahasiswa mengulang kata yang sama dalam satu paragraf, ditemukan penggunaan sinonim yang definisinya kurang relevan dengan konteks kalimat, penggunaan hiponim yang belu merujuk pada unsur yang lebih besar sehingga kepaduan antar kalimat dan antar paragraf belum terhubung dengan baik. Untuk koherensi, ditemukan satu kesalahan sama yang banyak dilakukan mahasiswa adalah pada penggunaan pola syarat hasil pada setiap paragraf sehingga kelogisan antar kalimat dan antar paragraf belum dapat terbentuk. Berdasarkan hasil tersebut dapat disimpulkan bahwa mahasiswa lebih banyak melakukan kekeliruan pada aspek kohesi dibandingkan dengan koherensi sehingga dengan temuan ini dapat diambil langkah lanjutan untuk dapat meningkatkan kualitas tulisan yang lebih padu, dan dapat dipahami oleh pembaca.
\end{abstract}

Kata kunci: Kohesi; Koherensi ; Makalah

\begin{abstract}
This paper aims to discuss and examine student writing in terms of coherence between sentences and coherence between paragraphs. The object of this research is student papers. Papers are an indicator of the characteristics and patterns of students in writing. Based on writing, it can be seen the flow and patterns of thinking. Therefore coherence between sentences and between paragraphs is very important so that writing can be
\end{abstract}


understood properly and have a systematic structure. Cohesion and coherence as well as the correct language order are very important to create a flow of thinking that can be accepted and understood by readers. The data in this study are the writings of the papers of Indonesian language and literature education study programs. Collecting data in this study using the documentation method. The data collection technique uses the reading note technique. Based on the results of the study, it was found that students repeated the same word in one paragraph, it was found that the use of synonyms is less relevant to the context of the sentence, the use of hyponyms that do not refer to larger elements so that the cohesiveness between sentences and between paragraphs is not well connected. For coherence, it was found that one common mistake that many students made was in the use of the result requirement pattern in each paragraph so that the logic between sentences and between paragraphs could not be formed. Based on these results it can be concluded that students make more mistakes in the cohesion aspect than coherence so that with this finding further steps can be taken to improve the quality of writing that is more coherent, good, and can be understood by readers.

\section{Keywords: Cohesion; Coherence; Students Paper}

\section{PENDAHULUAN}

Wacana merupakan sebuah pikiran pokok lengkap dinyatakan dalam bentuk lisan atau tulisan. Pikiran pokok yang dinyatakan pada bentuk tulisan terdiri dari gabungan kata, kalimat, paragraf, memperhatikan antar sutu struktur dengan struktur yang sistematis dan berhubungan antara paragraph yang satu dengan paragraph yang lainnya. Sebagai struktur yang mengatur ketepatan penggunaan dan penempatan penanda proposisi dalam wacana adalah kohesi dan koherensi. Wacana dikatakan sebagai wacana yang padu apabila ada keterhubungan dan keruntutan antarkalimat. Bahasa memiliki bentuk dan makna sehingga wacana dapat dikelompokkan menjadi dua yaitu kohesi dan kohesi. Kohesi mengkaji hubungan bentuk dan koherensi mengkaji hubungan makna (Sumarlam, 2003:23). Kohesi mengatur keserasian antarkalimat dalam sebuah wacana sedangkan koherensi kepaduan makna antar kalimat kepaduan makna paragraf yang satu dengan paragraf lainya menjadi sesuai dengan penjelasan Djajasudarma (2006: 44) yang mengemukakan kohesi adalah keterhubungan atau perpautan antar bentuk sehingga dapat menciptakan pemahaman yang utuh. Koherensi merujuk pada keterhubungan dan keterpaduan makna sehingga konteks wacana yang utuh dapat juga dipahami secara utuh oleh pikiran pembaca.

Mulyana (2005: 26) memaparkan bahwa kohesi adalah kepaduan bentuk yang dapat membentuk struktur kalimat secara utuh. Untuk memperoleh kepaduan dalam wacana, maka kalimat-kalimat penyusunnya harus bersifat kohesif. Penginterpretasian sebuah wacana hanya dapat dilakukan jika rangkaian kalimat-kalimatnya sistematis terstruktur, efektif, dan tidak rancu.

Yuwono memaparkan bahwa unsur semantis berpengaruh terhadap wacana karena keutuhan dan keterkaitan antar wacana yang saling mempengaruhi (Kushartanti, dkk., 2005:96). Senada dengan pendapatnya Alwi (2003:427) memaparkan bahwa kohesi 
memiliki hubungan gramatikal dan semantis dalam wacana. Kohesi yang baik akan melahirkan wacana yang interpretatif dan padu.

Halliday dan Hasan (Hasnah, 2018:222) mengemukakan bahwa dalam teks dan nonteks yang membedakan keduanya adalah keterkaitan makna substantif. Teks dapat diukur kualitasnya dengan unsur kohesi dan koherensi. Kohesi mengukur kualitas dari aspek bentuk dan koherensi mengukur dari aspek makna sehingga teks dapat dipahami dan ditafsirkan pembaca sesuai dengan pemahamannya. himpunan hubungan makna yang umum untuk semua kelas teks yang membedakan teks dari nonteks dan saling terkait makna substantif teks satu sama lain. Jadi, dari semua pendapat di atas dapat disimpulkan bahwa kohesi adalah hubungan antarunsur dalam wacana yang dinyatakan secara eksplisit dan ditandai oleh unsur bentuk.

Djajasudarma (2012: 64-65) membagi kohesi menjadi dua bagian yaitu kohesi leksikal dan kohesi gramatikal. Kohesi leksikal merupakan kepaduan pembentukan kosakata yang dapat dicapai dalam wacana melalui pemilihan kata yang tepat supaya menjadi kalimat yang kohesif dalam satu wacana. Kohesi leksikal antara lain penggunaan kata secara berulang dalam satu wacana, sinonim, hiponim, dan kolokasi. Pengulangan kata adalah kekeliruan yang paling sering dilakukan oleh mahasiswa sehingga menyebabkan kalimat yang terbentuk menjadi kurang efektif. Penggunaan sinonim yang kurang tepat dalam konteks penggunaan dalam pergantian kalimat karena satu diksi atau kata dengan kata lainnya meskipun sama belum tentu sesuai dipasangkan dalam kalimat yang sama. Misalnya untuk penyebutan jenis kelamin pada bayi, tidak tepat jika disebut pria meskipun bersinonim dengan laki-laki. Penggunaan hiponim yang kurang tepat karena tidak mengacu pada pada unsur yang dimaksud, dan penggunaan kolokasi yang kurang tepat pendampingan atau penggabungannya. Kolokasi akan tepat jika memasangkan verba dengan nomina, nomina dengan nomina, dan nomina dengan ajektiv.

Kohesi gramatikal adalah perpautan bentuk antar kalimat-kalimat yang diwujudkan dalam sistem gramatikal (Hidayat, 2016: 34). Dalam kohesi gramatikal ada beberapa bagian yaitu.

a. Referensi adalah pengacuan, referensi orang adalah pengacuan dengan fungsi atau peran didalam situasi tuturan melalui kategori orang (persona). Referensi orang terdiri dari tiga jenis yaitu, referensi orang pertama, referensi orang kedua, dan referensi orang ketiga.

b. Subsitusi adalah penyulihan merupakan proses atau hasil penggantian unsur bahasa dalam satuan yang lebih besar untuk memperoleh unsur-unsur pembeda atau untuk menjelaskan suatu struktur tertentu.

c. Ellipsis adalah penghilangan merupakan pesesapan suatu unsur bahasa yang maknanya telah diketahui sebelumnya berdasarkan konteks.

d. Konjungsi adalah sebagai kata penghubung dari dua kalimat atau lebih

Koherensi membahas hubungan semantis dalam wacana yang diwujudkan dalam hubungan antar kalimat. Dalam kalimat hubungan tersebut ditandai dengan (1) hubungan sebab akibat yang memiliki ciri kalimat mengandung kata penghubung oleh karena itu, oleh sebab itu, sehingga, karena itu, sebab itulah, (2) akibat sebab yang ditandai sengan kata penghubungnya pernyataan akibatnya ada di tengah, (3) hubungan syarat hasil yaitu 
kalimat pernyataan yang ditandai dengan jika, asal, asalkan, apabila, (4) hubungan sarana tujuan adalah kalimat yang ditandai dengan penghubung karena, sebab, dan menjelaskan tujuan dan dengan cara, (5) hubungan alasan tindakan adalah penyataan yang mengandung alasan sesuatu itu dilakukan yang ditandai dengan penghubung karena ,sebab dan dapat diletakkan di awal kalimat, dan beberapa hubungan lain dalam kalimat.

Koherensi merupakan kepaduan makna antar kalimat dalam satu wacana sehingga menjadi wacana yang logis. Darma (2014: 62) menjelaskan dalam teks kekoherensiannya didasarkan pada kesesuaian struktur sintaksis dan pemilihan diksi. Hal ini juga dikemukakan oleh Hidayat (2016:34) yang memaparkan bahwa dalam nonteks koherensi terletak pada aspek tuturan, keutuhan dan kalimat yang final meskipun tidak terdiri dari satuan lengkap secara fungsional. Keterpautan bentuk dan makna dalam suatu wacana sangat penting untuk meluruskan jalannya gagasan yang dituangkan pada tulisan. Selain itu membantu memudahkan penikmat memahami isi dari sebuah wacana. Ketika pembaca memahami dari wacana berarti sebagian besar kohesi dan koherensi sudah sesuai kaidah. Apalagi dalam proses pembuatan makalah sangat diperlukan untuk mengetahui bentuk dan penempatan kohesi atau koherensi karena ketika membuat wacana sangat penting untuk mengetahui keduanya supaya wacana tersebut bisa dipahami oleh pembaca. Ketika wacana yang dibuat tidak memenuhi keduanya, maka makalah tersebut sulit untuk dipahami oleh para pembaca. Ketika para pembaca kesulitan dalam memahami makalah tersebut, secara tidak langsung akan timbul yang namanya salah tafsir.

Pada dasarnya tidak semua mahasiswa paham terhadap kohesi dan koherensi. Ada beberapa yang paham ada juga yang kurang memahami mengenai penempatan kohesi dan koherensi dalam wacana. Penyebab kekurangpahaman mahasiswa antara lain adalah kurangnya perbendaharaan kosakata pada kreativitas penulisan sehingga cenderung menulis kata yang berulang dan terjadi kerancuan penggunaan sinonim. mahasiswa kurang teliti ketika membuat wacana di dalam makalah, belum membuat kerangka konsep saat akan menulis sehingga belum terarah dan memiliki tujuan yang hendak ditulis.

Dunkin dan Biddle mengemukakan bahwa proses pembelajaran sangat berpengaruh pada hasil belajar. Proses pembelajaran pada keterampilan menulis merupakan satu di antara empat keterampilan berbahasa yang sangat penting. Peningkatan keterampilan menulis mempengaruhi aspek kebahasaan yang harus diupayakan secara efektif dan efisien. Kegiatan menulis merupakan aspek produktif yang dapat menjadi indikator kemampuan mahasiswa dalam proses pembelajaran. Bekal keterampilan menulis yang baik dapat bermanfaat untuk kehidupan selanjutnya dalam bidang pendidikan. Seorang mahasiswa yang terampil menulis, akan produktif menghasilkan karya (Budiyono, 2014:2). Dalam perkuliahan, mahasiswa akan dihadapkan pada kegiatan menulis hamper setiap hari untuk kewajiban menyelesaikan tugas. Satu di antaranya tulisan mahasiswa adalah makalah yang merupakan penugasan dari dosen untuk dipresentasikan dan dipahami oleh yang mendengarkan.

Makalah sebagai dokumen penting dalam proses perkuliahan, bukan hanya sebagai dokumen tetapi sebagai pisau kajian keilmuan dalam seminar, presentasi, dan orasi ilmiah di dalam kelas. Ketika wacana yang ada di dalam makalah tidak terstruktur, penempatan 
kohesi dan koherensi pada paragraf kurang tepat maka poin ide pokok dan gagasan tidak akan jelas. Imbas kekacauan bukan hanya diterima oleh mahasiswa yang presentasi, pada audien yang sedang mendengarkan diskusi tetapi bagi dosen yang akan memantau jalannya diskusi juga akan terganggu. Para khalayak yang membaca makalah tersebut juga bisa merasakan kekacauan untuk memahami kajian yang dibahas.

Berdasarkan dari observasi yang sudah dilakukan maka penelitian ini perlu dilakukan kohesi dan koherensi pada makalah mahasiswa. Dari makalah yang sudah diteliti peneliti bisa mengetahui kesalahan dan kebenaran makalah mahsiswa dalam penggunaan kohesi dan koherensi. Penelitian ini dapat digunakan sebagai petunjuk dan pengathuan tentang hasil tulisan mahasiswa yang masih memerlukan peningkatan dan perbaikan, dan juga sebagai alat evaluasi bagi dosen pengampu matakuliah keterampilan menulis bahwa strategi yang digunakan untuk proses pembelajaran menulis perlu dikaji ulang. Penelitian mengenai kohesi dan koherensi pada makalah mahsiswa merupakan penelitian yang menarik untuk diteliti karena dari penelitian ini bisa mengetahui seberapa besar pemahaman mahasiswa dalam membuat makalah yang kohesif.

Berdasarkan paparan di muka, penelitian ini akan mengkaji perwujudan kohesi dan koherensi pada tulisan makalah mahasiswa dan bentuk kesalahan koherensi dan koherensi serta perbandingan kesalahan yang terjadi antara keduanya sehingga dapat diketahui mahasiswa lebih banyak melakukan kesalahan dalam aspek kohesi atau koherensi yang akan menjadi indikator dan evaluasi pada peningkatan pembelajaran keterampilan menulis selanjutnya.

\section{METODE PENELITIAN}

Jenis penelitian yang digunakan adalah penelitian kualitatif dengan pendekatan deskriptif. Penelitian kualitatif merupakan jenis penelitian yang berusaha memahami fenomena yang muncul di sekitar (Moleong, 2007:6). Sedangkan pendekatan deskriptif merupakan data yang diperoleh berupa bahasa tulisan makalah mahasiswa. Data merupakan hasil catatan yang akan dianalisis oleh peneliti. Data yang digunakan dalam penelitian ini adalah paragraf yang mengandung kohesi dan koherensi yang terdapat pada makalah mahasiswa program studi Pendidikan Bahasa dan Sastra Indonesia STKIP PGRI Bangkalan.

Metode pengumpulan data menggunakan metode dokumentasi teknik baca catat. Langkah-langkah dalam mencatat yaitu mengidentifikasi bentuk kohesi dan bentuk koherensi pada makalah. Setelah mengidentifikasi kemudian peneliti mengevaluasi kebenaran dari bentuk kohesi dan bentuk koherensi. Untuk mempermudah analisis data disediakan grafik sesuai dengan data kohesi dan koherensi. Adapun prosedur analisis data dalam penelitian ini yaitu: 1) seleksi dan pengklasifikasian data, 2) penyajian dari hasil analisis data, temuan data dikaji dengan teori yang digunakan.

\section{PEMBAHASAN}

\section{Perwujudan Kohesi}

Berdasarkan hasil analisis yang dilakukan, pembahasan ini secara sistematis akan dipaparkan sehingga satu persatu tujuan penelitian dapat terjawab. Pada bagian ini akan membahas mengenai kohesi makalah mahasiswa angkatan 2018 program studi 
pendidikan Bahasa dan Sastra Indonesia STKIP PGRI Bangkalan. Berikut ini data yang mengacu pada kohesi dari pengulangan kata.

Puji syukur kehadirat Tuhan Yang Maha Esa, yang atas berkah dan rahmat-Nya, kami dapat menyelesaikan tugas makalah yang berjudul "POLA-POLA FIKSI". Dengan selesainya makalah ini tidak terlepas dari bantuan banyak pihak yang telah memberikan masukan-masukan kepada penulis. Makalah ini disusun untuk para pembaca dapat memperluas pengetahuan ............. Penulis dari makalah ini (data 1/kohesi)

Data di atas merupakan penggalan makalah mahasiswa program studi pendidikan Bahasa dan Sastra Indonesia angkatan 2018. Data tersebut berasal dari dari bagian kata pengantar, dari penggalan wacana itu ditemukan pengulangan kata berulang kali dalam suatu paragraf. Pengulangan dalam data kalimat tersebut yaitu kata-kata yang dicetak miring makalah. Pada satu paragraf pengulangan kata makalah ini diulang sebanyak empat kali, yaitu terletak pada kalimat pertama yang terletak diakhir kalimat. Kata makalah diulang pada kalimat kedua terletak pada awal kalimat untuk mempertegas kalimat pertama. Kata makalah mengalami pengulangan pada kalimat ketiga terjadi diawal kata kemudian pengulangan kata makalah terjadi pada kalimat keempat tepat di tengah kalimat.

Pengulangan dapat diganti dengan cara substitusi misal pada baris kedua data 1 sudah muncul kata tugas yang merujuk pada makalah sehingga kata makalah tidak perlu dimunculkan kembali. Pengulangan dengan tujuan penegasan dapat dilakukan dengan cara substitusi sehingga paragraph menjadi padu dan tidak jenuh dengan kemunculan kata-kata yang sama.

Berikut data lain dari penulisan makalah mahasiswa ...akhirnya penulis bisa menyelesaikan tugas kelompok ini dengan berusaha semaksimal mungkin, ............ penulis menyadari makalah (data 2/kohesi)

Persoalan yang sama muncul pada data 2 yaitu pengulangan satu kata yang sama sebanyak lima kali dalam satu paragraf, dan pengulangan juga terjadi dalam tataran kalimat. Pengulangan semacam ini menjadikan kalimat menyimpang dari aspek keefektifan dan cenderung terjadi pemborosan kata. Kalimat dapat menjadi lebih efektif tanpa mengulang kata yang sama karena kata penulis sudah merujuk pada pembuat makalah. Pengulangan digunakan untuk mengulang suatu preposisi atau bagian dari preposisi untuk menciptakan hubungan kohesif. Berdasarkan temuan data satu dan data dua mengacu pada teori yang dikemukakan disimpulkan bahwa tulisan mahasiswa dalam makalah belum padu, hal ini munculnya pengulangan kata secara berlebihan. Pengulangan kata bisa diganti substitusi dan referensi sehingga dalam wacana itu bervariasi pilihan katanya dan pembaca tidak jenuh dan senang membaca wacana itu.

Berbeda dengan data 3 berikut ini, pengulangan kata penulis dibutuhkan untuk menunjukkan bahwa yang dimaksud adalah dua penulis yang berbeda. Pengulangan semacam ini diperlukan agar tulisan dapat memiliki kepaduan dan dapat dipahami oleh pembaca karena bagian referensinya jelas.

Berikut data 3: 
Berbeda dengan penulis narasi nonfiksi, penulis fiksi tidaklah memusatkan perhatiannya pada apa-apa yang telah terjadi secara aktual, ................. tugas penulis fiksi untuk membuat tokoh-tokoh imajinatif menjadi hidup dan karyanya itu. Untuk melakukan hal ini, penulis .........(data 3/kohesi).

Berdasarkan data tersebut referensi dibutuhkan sebagai pembeda antara pengulangan yang disebutkan dalam tulisan karena ada dua penulis yang dibahas yaitu penulis fiksi dan penulis nonfiksi sehingga untuk memperjelas pikiran yang dimaksud, maka kata penulis dengan sengaja disebutkan secara berulang. Dari penggalan data tersebut ada lima pengulangan kata penulis terletak pada kalimat pertama bahkan sampai dua pengulangan kata dalam satu kalimat. Pengulangan kata penulis diakhir koma (,) dan diawal koma pada kalimat pertama. Pengulangan kata penulis juga diletakkan pada kalimat kedua berada di tengah kalimat kedua. Kata penulis juga diulang pada kalimat keempat dan kalimat kelima.

Hanafiah (2014:141) mengemukakan bahwa referensi ada dua yaitu eksofora dan endofora. Eksofora merupakan pereferensian yang mengacu pada alam sekitar sedangkan pereferensian endofora adalah pengacuan pada yang ada di dalam teks. Berdasarkan teori tersebut pemakaian referensi secara tepat dan benar pada makalah mahasiswa di atas wacana mempunyai kepaduan bentuk baik dari yang terkecil sampai kepada yang terbesar sehingga unsur-unsur dalam wacana itu berkesinambungan dengan unsur-unsur lainnya.

\section{Sinonim}

Berikut ini data yang berhubugan dengan sinonim:

Tujuan dari penulisan makalah ini penulis sangat berharap makalah ini dapat menjadi referensi bagi kita sebagai mahasiswa luas maupun khalayak umum yang membacanya. Agar dapat mengetahui hakikat manusia menurut agama, peranan agama, serta persyaratan konselor menjadi referensi bagi kita sebagai mahasiswa luas atau khalayak umum yang membacanya agar lebih mengetahui tentang landasan religious (data 4/kohesi)

Dari penggalan data di atas terdapat sinonim atau persamaan frasa mahasiswa luas yang merujuk terhadap frasa khalayak umum. Penggalan data di atas terdapat dua sinonim atau persamaan kata pada kalimat pertema dan kalimat kedua juga diulang kembali. Penggalan data yang dikutip merupakan satu paragraf. Satu paragraf terdiri dua kalimat. Meski dua kalimat dalam satu paragraf tetapi maksud dan tujuan penulis bisa dipahami. Ide pokok dari paragraf tersebut tampak.

Sinonim adalah bentuk leksikal yang secara semantic memiliki makna yang sama dengan kata lain (Djajasudarma, 2012: 65). Verhaar memberikan pengertian sinonim adalah kata, frase, atau kalimat yang bermakna sama untuk memberikan pengungkapan lain dengan konteks yang harus sesuai dengan wacana yang berfungsi sebagai penjalin kepaduan antara satuan lingual yang memiliki kesamaan arti atau makna. Jadi, dapat dikatakan bahwa sinonim adalah unsur penting dalam menciptakan wacana yang efektif dan padu (Anjani, 2013).

Sesuai dengan definisi tersebut, data 4 kemunculan sinonim pada frase mahasiswa luas dan khalayak umum dapat dipilih satu di antaranya agar kalimat menjadi lebih efektif. Frasa yang dicetak miring mahasiswa luas sepadan dengan frasa yang dicetak miring khalayak umum. Jika ditafsirkan secara rinci kata mahasiswa adalah kumpulan 
individu yang berada dalam satu naungan perguruan tinggi untuk menempuh jenjang S1, S-2, dan S-3 sedangkan kata luas merupakan makna yang merujuk kepada hal yang lebih banyak lingkupnya baik jumlah manusia atau benda lainnya. Jika dua kata itu digabuang menjadi frasa mahasiswa luas, maka tafsirnya akan berubah. Tafsir mahasiswa yang sebelumnya hanya dalam lingkup individu yang berada dalam satu naugan perguruan tinggi. Adanya gabunggan kata luas maka tafsir itu akan berubah menjadi lebih luas, tafsir mahasiswa berubah sebagai bagian dari masyarakat umum. Mahasiswa dianggap sebagai bagian dari pembaca umum tidak dibedakan kuliah atau tidak, setatus sosial harkat derajatnya. Sedangkan frasa yang dicetak miring khalayak umum mempunyai tafsir masarakat umum tanpa membedakan status apapun.

Sinonim juga muncul pada data berikut ini:

Menurut sifat hakiki manusia adalah makhluk beragama (homo religius), yaitu makhluk yang mempunyai fitrah untuk memahami dan menerima nilai-nilai kebenaran yang bersumber dari agama, .........................(data $6 /$ kohesi)

Data di atas penggalan makalah mahasiswa angkatan 2018 mata kuliah bimbingan konseling. Dari penggalan data tersebut terdapat sinonim atau persamaan kata manusia. Kata manusia bersinonim dengan kata makhluk. Penggalan data di atas terdapat dua sinonim atau persamaan kata pada kalimat pertema, kemudian sinonim atau persamaan kata itu diulang pada kalimat kedua. Sedangkan pada kalimat ketiga sinonim itu hanya diulang pada kata manusia saja. Penggalan data yang dikutip merupakan satu paragraf. Satu paragraf terdiri tiga kalimat. Meski tiga kalimat dalam satu paragraf tetapi maksud dan tujuan penulis bisa dipahami. Ide pokok dari paragraf tersebut jelas.

Penggalan data dari makalah mahasiswa mata kuliah bimbingan konseling bisa dikatakan kohesi karena sinonim atau persamaan kata yang digunakan merupakan kata yang mempunyai makna sama tetapi bentuk dari tulisannya berbeda. Kata yang dicetak miring manusia sepadan dengan kata yang dicetak miring makhluk. Jika ditafsirkan secara rinci kata manusia merupakan ciptaan tuhan yang paling sempurna selain makhluk yang lain. Manusia dilengkapi dengan akal pikiran jernih untuk berpikir bertakwa kepada Tuhan yang Maha Esa, mengikuti aturan-Nya dan menjahui larangan-Nya. Kata manusia adalah kata khusus dari kata makhluk, kata umum dari kata manusia adalah makhluk.

\section{Substitusi}

Dalam kohesi gramatikal ada beberapa bagian yaitu, referensi, subsitusi, ellipsis, dan konjungsi. Berikut ini data yang menunjukkan kemunculan substitusi:

Dengan mengamalkan ajaran agama, berarti manusia telah mewujudkan jati dirinya, identitas dirinya yang hakiki, yaitu sebagai 'abdullah' (hamba Allah) dan khalifah di muka bumi. Manusia yang diciptakan Allah SWT sebagai khalifah memiliki kemerdekaan untuk mengembangkan diri. Sebagai hamba dan khalifah Allah, manusia mempunyai tugas suci, yaitu ibadah atau mengabdi kepada-Nya (data 7/kohesi)

Subsitusi (penyulihan) merupakan proses atau hasil penggantian unsur bahasa dalam satuan yang lebih besar untuk memperoleh unsur-unsur pembeda atau untuk menjelaskan suatu struktur tertentu. Data tersebut menggunakan subsitusi atau penyulihan kata manusia dengan kata abdullah serta kata khalifah. Penggunaan subsitusi 
ini disusun mulai dari unsur kata paling mudah kata manusia dengan kata abdullah serta kata khalifah. Kata manusia merupakan kata pasaran atau sering digunakan dalam interaksi antar sesama, sehingga kata ini diasumsikan sebagai kata yang mudah dipahami aau unsur biasa. Kata abdullah memmpunyai tafsir sepadang dengan kata manusia, samasama hamba Allah, tetapi jarang digunakan dalam komunikasi karena kata abdullah berasal dari bahasa Arab, jika tidak tahu bahasa Arab tentu asing kata abdullah. Sedangkan kata khalifah merupakan persamaan kata dari kata manusia, hanya saja kata khalifah tidak biasa digunakan dalam sehari-hari.

\section{Konjungsi}

Berikut data konjungsi:

Pendidikan pada dasarnya adalah media dalam mendidik dan mengembangkan potensi-potensi kemanusiaan yang primudial. Pendidikan sejatinya adalah gerbang untuk mengantar manusia menuju peradaban yang lebih tinggi dengan berlandaskan pada keselarasan hubungan manusia, lingkungan, dan sang pencipta (data 8/kohesi)

Penggalan data di atas terdapat konjungsi yang menghubungkan unsur yang satu dengan unsur yang lainnya baik kata, frasa, klausa dan kalimat. Konjungsi yang digunakan yaitu pada kalimat pertama dengan menggunakan konjungsi dan. Konjungsi juga diulang pada kalimat kedua untuk, konjungsi untuk untuk menegaskankan bahwa pendidikan sebagai wawasan yang akan menuntun manusia menjadi lebih pandai, lebih bijak, dan mampu bersaing di era kemajuan. Konjungsi dengan juga diulang kembali untuk menjelaskan kecerdasan manusia harus digunakan sesuai hubungan manusia dengan manusia lainnya. Artinya meskipun manusia sudah pandai, kepandaianya harus tepat sasaran.

Demokrasi pendidikan merupakan pandangan hidup yang mengutamakan hak dan kewajiban serta perlawanan yang sama di dalam berlangsungnya proses pendidikan antara pendidik dan anak didik, serta dengan pengelolaan pendidikan tanpa menyandang suku, kebangsaan, agama maupun ras, dan tidak membedakan antara si miskin dan si kaya, karena setiap warga negara berhak mendapatkan pendidikan (data 9/kohesi)

Penggalan data di atas terdapat konjungsi yang menghubungkan unsur yang satu dengan unsur yang lainnya baik kata, frasa, klausa dan kalimat. Konjungsi yang digunakan yaitu serta. Konjunsi serta berfungsi untuk mengembangkan kalimat. Konjungsi juga diulang kembali pada kalimat yang sama dan dengan serta. Fungsi dan kedudukan konjungsi memperluas gagasan, selain itu untuk memperjelas dari kalimat tersebut. Bukan hanya itu, tetapi konjungsi dan, dan konjungsi karena diulang kembali.

Konjungsi merupakan sebagai kata penghubung dari dua kalimat atau lebih (Darma, 2014: 58). Konjungsi tersebut seperti: dan, atau, tetapi, ketika, seandainya, supaya, pun, seperti, oleh, karena, sehingga, bahwa, untuk, saat itu, kemudian, namun.

Konjungsi adalah kata penghubung yang digunakan dalam wacana untuk menghubungkan satuan terkecil sampai pada unsur yang lebih besar daam wacana. Hasan dan Baryadi (Nurfitriani, 2018:41) alat kohesi gramatikal meliputi konjungsi (conjugtion) 
dan ungkapan transisi, penunjukan (reference), penggantian (substitution), dan pelesapan (ellipsis).

\section{Perwujudan Koherensi}

Koherensi merupakan keterpaduan makna antar kalimat sehingga menjadi wacana yang logis. Koherensi juga sebagai interpretasi ke dalam satu teks berikut ini data yang mengacu pada koherensi.

Setiap manusia mempunyai dua potensi atau kecenderungan yaitu "takwa" (beriman dan beramal shaleh, atau berakhlak mulia), dan "fujur" (musyrik, kafir, munafik, fasik, atau berakhlak buruk). Kemampuan individu (anak) untuk dapat mengembangkan potensi "takwa" dan mengembangkan "fujur"-nya, tidak secara otomatis atau berkembang dengan sendirinya, tetapi memerlukan bantuan orang lain, yaitu melalui pendidikan agama (bimbingan, pengajaran, dan pelatihan), terutama dari orangtuanya sebagai pendidik pertama dan utama di lingkungan keluarga.

Data di atas bisa dikatan koherensi yantu ditunjukkan pada makna kalimat pertama (setiap manusia sudah dilingkapi dengan potensi), beberapa potensi dan kecendrungan manusia sangat beragam. Kalimat kedua masih dalam konteks potensi manusia, tetapi ada penanda hubungan koherensi yaitu syarat hasil. Yang dimaksud hasil dalam koherensi mengacu pada ide poko kalimat pertama yaitu manusia dilengkapi potensi atau kecendrungan, hasil manusia untuk cendrung bertaqwa, berakhlak sudah lengkap. Sedangkan yang dimaksud syarat penanda dalam koherensi dijabarkan makna kalimat kedua. Kalimat kedua sangat jelas ide pokonya, meski manusia sudah dilengkapi dengan potensi atau kecendrungan, potensi dan kecendrugan agar tampak hasilnya maka dibutuhkan upaya atau syarat. Syaratnya yaitu membutuhkan pendidikan serta bantuan orang lain. Koherensi merupakan kepaduan struktur dan makna antar kalimat dalam satu paragraf sehingga menjadi wacana yang logis. Bisa diasumsikan bahwa data tersebut sebagai data yang koheren.

\section{SIMPULAN}

Berdasarkan data dan temuan serta teori dapat disimpulkan bahwa tulisan mahasiswa dalam makalah ditemukan belum padu yang dapat diketahui dari kemunculan pengulangan yang berakibat pada kekurang efektifan kalimat dan pemborosan kata. Pengulangan dapat diubah dengan menggunakan substitusi dan referensi agar menjadi kalimat yang efektif. Kemunculan penggunaan sinonim yang kurang tepat karena digunakan bukan untuk memperjelas sehingga penggunaan sinonim dapat dihilangkan dengan memilih satu di antara kata yang sesuai dengan konteks wacana. Secara kolektif mahasiswa lebih banyak melakukan kesalahan pada aspek kohesi dibandingkan dengan kesalahan pada aspek koherensi. Menulis dengan menggunakan konteks lebih mudah bagi mahasiswa dibandingkan menulis dengan konsep karena menulis dengan konteks membuat pikiran lebih mengalir dan alur berpikirnya sistematis sesuai dengan yang dipikirkan. 


\section{UCAPAN TERIMA KASIH}

Penelitian mendapatkan dukungan dan motivasi dari STKIP PGRI Bangkalan yang terus memberikan motivasi untuk terus melakukan kegiatan tridharma perguruan tinggi dosen. Ucapan terima kasih juga kepada penulis kedua yang telah berkontribusi pada penyelesaian penelitian dan seluruh mahasiswa yang bersedia tulisannya menjadi objek penelitian ini.

\section{REFERENSI}

Alwi, H. (2003). Tata Bahasa Baku Bahasa Indonesia. Jakarta: Balai Pustaka

Amin, M. (2016). Kohesi dan Koherensi dalam Artikel Ilmiah Populer Radar Sulteng. Jurnal Bahasantodea, 48-56.

Anjani, E, G. (2013). Kohesi dan Koherensi Wacana Stand Up Comedy Prancis dan Indonesia. Kawistara: Jurnal Humaniora dan Ilmu Sosial, 227-334.

Budiyono, H. (2015). Keutuhan dan Kepaduan Paragraf Tulisan Mahasiswa Program Studi Psikologi Fkik Universitas Jambi. Pena : Jurnal Pendidikan Bahasa Dan Sastra, 1-12.

Chaer, A. (2003). Linguistik Umum. Jakarta: Rienika Cipta.

Darma, Y. A. (2014). Analisis Wacana Kritis. Bandung: PT Retika Aditama.

Djajasudarma, F. (2006). Wacana Pemahaman dan Hubungan Antarunsur. Bandung: PT Revika Aditama.

Djajasudarma, F. (2012). Wacana dan Pragmatik. Bandung: PT Retika Aditama.

Hanafiah, W. (2014). Analisis Kohesi dan Koherensi pada Wacana Bulletin Jumat. Jurnal Epigram, 135-15.

Hidayat, N. W. (2016). Kohesi dan Koherensi Dalam Karangan Narasi Siswa Kelas VII A SMP Islam Bustanul Pakusari Jember. Jurnal Edukasi. 33-35.

Kushartanti., Yuwuno, U. (2005). Pesona Bahasa: Langkah Awal Memahami Linguistik. Jakarta: PT Gramedia Pustaka Utama

Lukman, H., Darwi, M., Abbas, A. (2018). Perwujudan Kohesi dan Koherensi pada Jurnal Refleksi Guru Bahasa Indonesia SMP di Kabupaten Maros. Jurnal Ilmu Budaya, 222-229.

Moleong, L. J. (2007). Metodologi Penelitian Kualitatif. Bandung: Penerbit PT Remaja Rosdakarya Offset.

Mulyana. (2005). Kajian Wacana: Teori, Metode, \& Aplikasi Prinsip-prinsip Analisis Wacana. Yogyakarta: Tiara Wacana. 
Nurfitriani. (2018). Analisis Kohesi dan Koherensi dalam Proposal Mahasiswa PBSI. Jurnal Bahasa dan Sastra, 39-49.

Sumarlam. (2003). Analisis Wacana:Teori dan Praktik. Surakarta: Pustaka Cakra 